UDK 336.2(497.5)]:614.4

Preliminary communication

\title{
THE IMPACT OF COVID-19 ON TAX ADMINISTRATION IN THE REPUBLIC OF CROATIA*
}

\author{
Renata Perić PhD, Full Professor \\ Faculty of Law Osijek, University of Josip Juraj Strossmayer in Osijek \\ S. Radića 13, Croatia \\ rperic@pravos.hr
}

\author{
Emina Jerković, PhD, Assistant Professor \\ Faculty of Law Osijek, University of Josip Juraj Strossmayer in Osijek \\ S. Radića 13, Croatia \\ ekonjic@pravos.hr
}

\begin{abstract}
The crisis and special measures caused by the Covid-19 virus pandemic have greatly disrupted the business and survival of small and medium-sized enterprises, as well as larger industries. The state and its institutions were forced to take certain measures to facilitate the survival and continuation of business, and to save jobs for entrepreneurs and their employees. The Tax Administration is a state institution whose measures directly affect every business. So it was among the first to take some measures, i.e. to adjust its business and tax collection to the new situation. This paper discusses the first measures introduced, those from March and April 2020. It discusses the deferral or installment payment of due and deferred tax liabilities. The measure of deferral, installment payment of tax liability, is certainly the most important and most popular measure among taxpayers. It is explained how tax measures during a pandemic should look according to the recommendations of the Organization for Economic Co-operation and Development (OECD). We explain other measures that have been introduced to facilitate business. These are the extension of the deadline for filing income tax, the exemption from VAT, the enforcement procedure and the payment of the annual tax rate. Despite the measures taken so far, it is important to emphasize that the Covid-19 pandemic is still ongoing, and that according to some experts, a real crisis with visible consequences of the pandemic is still to be expected. Accordingly, it is to be expected that the current measures are very likely to be further changed, upgraded and adjusted as the situation changes.
\end{abstract}

This paper is a product of work that has been fully supported by the Faculty of Law Osijek, Josip Juraj Strossmayer University of Osijek, under the project No. IP-PRAVOS-21 "Fiscal policy and development of the public finance system". 
We consider it important to note that the framework of this paper does not allow a detailed analysis and that we are forced to limit ourselves exclusively to some aspects of the issue at hand.

Keywords: Covid-19, pandemic, Tax Administration, measures, taxpayers

\section{INTRODUCTION}

A new coronavirus emerged in Asia in the second half of 2019, spread to Europe at the beginning of 2020, and entered Croatia at the end of February 2020, when the first case of infection was recorded. The official name of the coronavirus named by the World Health Organisation is SARS-CoV-19, and the disease it causes is called coronavirus disease 2019, or COVID-19 for short.

As a result of these events, the jobs of the employed people were compromised. For this reason, the government was forced to take certain measures, i.e. to make some moves in order to make it easier for employers to fight such unprecedented situation. The government introduced a new measure in the form of compensation of salary costs to employers in the amount of HRK 4,000 per month per employee if they were unable to carry out their business activities in those months. Accordingly, the Tax Administration had to adopt certain measures. It could be said that this government institution is directly related to employers and measures in this situation, because business entities that were unable to operate were not able to pay all of its imposts. For this reason, the Government of the Republic of Croatia has adopted measures on several occasions to monitor the current situation.

This topic was chosen to take a closer look at the impact of this most current topic today on the Tax Administration, i.e. taxpayers and measures that seek to mitigate this extraordinary situation. The topic was also chosen because of the unprecedented situation in the new tax systems due to which it was necessary to modify the way in which both taxpayers are treated and taxes are paid in a situation when there is almost no taxable income.

"Apart from the fact that this pandemic has hit people's health hard, its growing economic impact can also be seen in national economies all over the world. In order to maintain a certain level of revenue to cover public expenditures, national and local governments had to secure funding through loan financing or different sources of finance available. This is especially true of parts of the economy that are significantly affected by the global pandemic, and this primarily refers to selling goods or services through direct contact, on business premises, because in order to protect human health and due to keeping a safe distance for the purpose of infectious disease control, there are restrictions related to carrying out the activities and even shutting down stores where services are provided and goods are sold."

Cipek, K.; Hadžić, A., Osvrt na porezne i ekonomske mjere tijekom globalne pandemije bolesti COVID-19, Porezni vjesnik, No. 10, October 2020., p. 27 


\section{TAX MEASURES RECOMMENDED BY THE OECD}

The Organisation for Economic Co-operation and Development has identified the following tax measures supporting the fight against COVID-19:

- Emergency response - Emergency response refers to the rapid adoption of measures. The necessity of such reaction is essential to combat permanent disruption in the market and the economy as a whole (i.e. to prevent economic collapse). Measures that are macroeconomic in nature have focused mainly on emergency liquidity assistance provided by central banks. The liquidity of entrepreneurs proved to be a threat to resume economic activities.

- Properly designed incentive packages - Based on the experience of the 20082009 crisis, it can be concluded that poorly designed incentive packages can have long-lasting negative consequences for global trade and national wellbeing. Although there is an urgent need to implement the measures as soon as possible, it should be taken into account that today's support does not cause permanent market distortion, including overcapacity, over-reliance on industrial investment by one country trying to solve its own economic problems by means of funds compounding the economic problems of other countries.

- Targeting measures at the sectors most severely affected by the crisis - It is necessary to take measures in favour of entrepreneurs whose businesses are most significantly directly impacted by the pandemic in order to avoid business decline or rescue companies that could not withstand the impact of the COVID-19 pandemic. This will reduce the risk that support spawns a new cohort of corporate zombies (companies that had difficulties in doing business even before the crisis) or national champions (corporations that are technically private businesses put in a dominant position in a national economy due to governmental policy) that could limit competition, slow down domestic productivity growth, distort international markets, hinder economic recovery, and in some cases exacerbate economic disparities.

- Targeting measures to support small- and medium-sized enterprises - This recommendation applies in particular to entrepreneurs operating in the service sector, as well as to those investing in strengthening health care and social security systems from which everybody benefits. Support for smalland medium-sized enterprises is less likely to cause excessive global market distortions. The biggest threat is expected in relation to employment and social stability. 
- Time limited support - Support measures should be time-limited by provisions of acts and automatically abolished once the crisis is over. This will help mitigate the risk that temporary support strengthens and outlives its purpose.

- Targeting support properly - It is also important for the economy who gets support. Governments should give priority to the most vulnerable, of course where possible, and give companies the freedom to decide how to spend the cash they receive. This differs from measures that link support to the consumption of certain goods or services, which can cause relative price distortion, send misleading signals to producers, and reduce consumer choice.

- Investments in society - In times of crisis, governments may have to invest in companies directly, and several have already announced their willingness, if need be, to invest in businesses struggling to survive in the market. Governments have also offered states the opportunity to buy shares in the troubled companies being bailed out as a way of strengthening accountability, equal share in terms of financial gains or losses, or as safeguards against foreign business takeovers.

- Measures that provide additional long-term benefits - Governments could adopt measures that provide additional benefits and thus help ensure that long-term policy objectives are not sacrificed for short-term economic support.

- Tax incentives and the availability of funding - Tax (fiscal) measures that have been announced or used at this stage include wide-ranging tax relief (e.g. reduced VAT and mandatory social security contributions), wage subsidies, unemployment benefits, utility payment deferral, mortgage relief, lump-sum payments to households, loans and loan guarantees for businesses, as well as government investments in companies whose stability has been disrupted by the crisis. This may also include bridging business loans by public investment banks and government agencies, government recapitalisation, or government loan guarantees.

Crisis conditions can dramatically reduce the availability of private funding. Increased economic uncertainty may encourage banks to be more selective in their investment conditions or to charge unusually high interest rates to now risky borrowers.

- $\quad$ Transparency of measures - The measures that have been proposed and implemented shall apply objective and transparent criteria for determining the eligibility of companies, especially to distinguish between temporary liquidity problems at which assistance should be targeted, and existing structural to solvency or 
performance of a company. The most important aspect of implementing measures in a crisis is for governments to be transparent about the measures they decide to adopt.

Transparency in terms of who benefits from subsidies and support programmes also contributes to public support at national level, as citizens can see that taxpayer money helps not only large multinational corporations, but also small- and medium-sized enterprises. Transparency also enables countries to know and exchange information about what each government is doing to boost the economy, thus reducing potential present and future tensions in the market, enabling countries to learn from each other's experiences, and paving the way for further international cooperation. $^{2}$

\section{MEASURES ADOPTED IN MARCH AND APRIL 2020}

The first amendment to the General Tax Act ${ }^{3}$ was published on 19 March 2020, and it defines special circumstances whose occurrence resulted in the measures adopted for the purpose of facilitating payment of tax liabilities such that they can be deferred or paid in instalments, provided that neither interest is charged during the deferment or instalment period nor the statute of limitations runs in the said period $^{4}$.

The measures adopted in March 2020 are the first measures adopted by the Government to assist taxpayers in the aftermath of the COVID-19 pandemic. They referred to:

- Tax payment deferral

- Reduction of monthly advance payments of personal income tax or corporate income tax

"The possibility of applying for tax payment deferral is provided for in Article 107(a) of the General Tax Act, which regulates tax payment in special circumstances. "Special circumstances" refer to an event or situation "which could not have been foreseen and affected, which endangers the life and health of citizens, property of greater value, significantly impairs the environment, disrupts economic activity or causes significant economic damage." If such special circumstances

\footnotetext{
2 [https://read.oecd-ilibrary.org/view/?ref=128_128575-o6raktc0aa\&title=Tax-and-Fiscal-Policy-in-Response-to-the-Coronavirus-Crisis], Accessed 10 April 2021.

3 Official Gazette No. 32/20.

$4 \quad$ Ibid.
} 
make it difficult or impossible to regularly settle tax liabilities, it is possible to defer and/or pay due tax liabilities in instalments."

This possibility applies to both taxpayers with income from professional activities of liberal professions who pay a lump-sum tax on their income earned in this way, and corporate taxpayers whose tax liability is payable as a lump-sum. ${ }^{6}$

It is impossible to reduce the monthly lump sum tax payable on a quarterly basis for such taxpayers. Pursuant to Article 3(5) of the Ordinance on estimated (lumpsum) taxation of liberal professions (independent personal services), ${ }^{7}$ in case of temporary suspension of such activity reported to both the competent authority with which the activity is registered and the competent Tax Administration office, no tax liability is determined for that period.

APPENDIX 1: Request for deferral of payment due to special circumstances

\begin{tabular}{|l|}
\hline MINISTRY OF FINANCE \\
\hline TAX ADMINISTRATION \\
\hline BRANCH OFFICE \\
\hline LOCAL BRANCH OFFICE \\
\hline PLACE AND DATE \\
\hline \multicolumn{1}{|c|}{ APPLICATION FOR TAX PAYMENT DEFERRAL } \\
DUE TO SPECIAL CIRCUMSTANCES \\
\hline \multicolumn{1}{|c|}{ 1. INFORMATION ABOUT THE APPLICANT } \\
\hline \multicolumn{1}{|c|}{ 1.2. COMPANY/NAME AND SUR- } \\
\hline $\begin{array}{l}\text { 1.1. SOCIAL SECURITY NUMBER (OIB) } \\
\text { NAME }\end{array}$ \\
\hline \\
\hline $\begin{array}{l}\text { In accordance with the General Tax Act and the Ordinance on the Implementation of the } \\
\text { General Tax Act, I am herewith submitting an application for deferred payment of tax liabili- } \\
\text { ties for a period of three months due to the occurrence of special circumstances caused by the } \\
\text { COVID-19 virus, or SARS-CoV-2 disease. }\end{array}$ \\
\hline \begin{tabular}{l} 
Facts relative to deciding on the application: \\
\hline
\end{tabular} \\
\hline
\end{tabular}

5 Mijatović, N., Porezne mjere u Republici Hrvatskoj za trajanja COVID(a) -19. (11.05.2020.), IUS-INFO.

6 Act on Tourist Board Membership Fees, Official Gazette No. 52/2019, Article 7.

7 Official Gazette No. 1/20. 
2.1. All tax liabilities were settled prior to the occurrence of special circumstances, or on the day of submitting this application, current debt recorded on the tax and accounting book of records amounts to less than HRK 200.

YES NO

2.2. Due to the occurrence of special circumstances, revenue/income were reduced by at least $20 \%$ in the month preceding the month of application, compared to the same period of the previous year.

\begin{tabular}{|lll}
\hline & YES & NO \\
\hline
\end{tabular}

2.3. Due to the occurrence of special circumstances, revenue/income is expected to be reduced by at least $20 \%$ in the next three months following the month of application, compared to the same period of the previous year.

\begin{tabular}{l}
\hline \multicolumn{1}{|c|}{ YES NO } \\
\hline $\begin{array}{l}\text { 2.4. Value of supplies of goods and services of more than HRK 7.5 million excluding VAT } \\
\text { was not recorded, the tax base is determined based upon the deliveries made, and the in- } \\
\text { voices issued on the basis of which the value added tax liability was determined have not been } \\
\text { charged. }\end{array}$
\end{tabular}

\begin{tabular}{|l|}
\hline \multicolumn{1}{|c|}{ YES } \\
\hline \\
\hline 3. EXPLANATORY STATEMENT \\
\hline \\
\hline $\begin{array}{l}\text { As an authorised person, I hereby declare under substantive and criminal liability that the } \\
\text { information provided is true and correct. }\end{array}$ \\
\hline SIGNATURE:
\end{tabular}

The second measure adopted in March 2020 referred to the reduction of the monthly advance payments of personal income and corporate income tax. "Pursuant to Article 107(a) of the General Tax Act, in relation to taxpayers who have suffered damage in their operations, i.e. they suspended and restricted their business operations due to special circumstances, the Tax Administration may not only postpone, but also reduce advance payment of personal income or corporate income tax to a smaller amount, i.e. to HRK 0.00. Natural persons engaged in a liberal profession (their income is determined on the basis of business records) and corporate taxpayers are entitled to the right to reduced advance payment. The Tax Administration may decide on a deferred tax liability:

- Ex officio, in the case of taxpayers whose activities have been suspended by the decision made by the competent authorities. The Tax Administration will ex officio determine advance personal income tax and advance corpo- 
rate income tax in the amount of HRK 0.00. This measure referred to tax liabilities based on advance tax payment for February 2020 (due in March 2020).

- Upon request of a taxpayer, if the taxpayer was adversely affected by special circumstances that have reduced their economic activity (this is also the case when some decisions made by the competent authorities have an indirect impact on and cause a decline in their economic activity), the taxpayer is eligible to apply for a reduction of advance tax payment, based upon which the Tax Administration may reduce advance personal income or corporate income tax or determine advance tax to amount HRK 0.00."8

On 2 April 2020, the Government of the Republic of Croatia presented the second (extended) package of economic measures aimed to further mitigate the adverse effects of COVID-19 on the economy and to preserve jobs. The measures are implemented by the Croatian Employment Service, the Croatian Bank for Reconstruction and Development (HBOR), the Tax Administration within the Ministry of Finance, and the Croatian Agency for SMEs, Innovation and Investments (HAMAG BICRO).

The second amendment to the General Tax Act published in the Official Gazette No. 42/20 on 7 April 2020 enabled taxpayers who are entitled to and have received support aimed at helping businesses retain their employees to be exempt from paying public imposts related to net salaries co-financed by the Croatian Employment Service. Furthermore, the aforementioned amendment stipulates that if a taxpayer's business activity is suspended or significantly hindered by a decision of the competent authority due to the occurrence of special circumstances, they may be fully or partially exempt from paying tax liabilities. It is also prescribed that during special circumstances, deadlines, payment of value-added tax on import and donations, the implementation of enforcement measures, interest rates, and procedural provisions may be prescribed in a different way. ${ }^{9}$

According to Mijatović, the measures adopted in April of the same year extend the existing Article 107(a) of the General Tax Act by legal amendments stipulating that a taxpayer who has exercised the right to support aimed at helping businesses retain their employees (i.e. co-financed salaries) during special circumstances shall not be charged any public imposts. If, due to these same special circumstances, a taxpayer is prohibited from working by a decision of the competent authority, or if, due to business conditions, a taxpayer's business activity is suspended or sig-

Mijatović, op. cit., note 5.

Act on Amendments to the General Tax Act, Official Gazette No. 42/20. 
nificantly hindered, they may be granted a full or partial tax exemption. The same legal changes allow for different regulatory deadlines, VAT payment referring to import and donations, enforcement proceedings, interest rates, and the like. If it is subsequently established on the basis of submitted incorrect or misleading data that the beneficiary of measures activated by special circumstances has obtained ill-gotten gains for themselves or another person, both the measures and tax deferral will be declared null and void (with other legal liability).

Amendments to the Ordinance on the Implementation of the General Tax Act ${ }^{10}$ were adopted a day later, on 8 April 2020. They further elaborate on Article 107(a) of the General Tax Act, which provides for the procedure of deferred and/or instalment payment of a due tax liability, exemption from contribution liabilities for co-financed net salaries, exemption from tax liabilities and the implementation of other special circumstances provisions. ${ }^{11}$ Also, all entrepreneurs, regardless of their annual income, may pay value-added tax when they collect payment of an invoice and not when they issue an invoice.

The deadline for filing tax returns as well as for submitting other forms and annual financial statements was extended to 30 June 2020. The due date established for the corporate income tax liability is 31 July 2020, while the obligation to pay fees to the Financial Agency is abolished upon their publication. ${ }^{12}$

Both amendments to the General Tax Act provided for the above-mentioned measures to be prescribed in more detail by the Minister of Finance in the Ordinance, and hence amendments to the Ordinance on the Implementation of the General Tax Act were adopted prescribing a code of conduct of tax authorities during special circumstances. ${ }^{13}$

\section{DEFERRAL AND/OR INSTALMENT PAYMENT OF A DUE DEFERRED TAX LIABILITY}

Not only the most important, but also the most popular measure among taxpayers is deferral, i.e. payment of tax liability in instalments. Any liability that falls due

\footnotetext{
10 Official Gazette No. 43/20.

11 [https://esavjetovanja.gov.hr/ECon/MainScreen?cv=1\&entityId=9961], Accessed 10 April 2021.

12 Frequently asked questions related to the package of measures adopted in the spring wave of the epidemic caused by the spread of the COVID-19 virus, Tax Administration, [https://www.porezna-uprava.hr/Stranice/NPP_COVID_mjere.aspx\#covid1?cv=1], Accessed 10 April 2021.

13 Ordinance and Amendment to the Ordinance on the Implementation of the General Tax Act, Official Gazette Nos. 45/19, 35/20, 43/20 and 50/20.
} 
before the expiry of the three-month period after 9 April $2020^{14}$ (entry into force of the amended Article 107(a) of the General Tax Act) is considered due. If special circumstances last longer, the period of up to three months may be extended for a further period of three months. ${ }^{15}$

Although it is a tax liability, the Ordinance on the Implementation of the General Tax Act needs to be interpreted more broadly as it can be applied to the majority of public imposts: taxes, fees, contributions, concession fees, and all imposts and charges determined and/or collected and/or supervised under special regulations within the jurisdiction of the tax authority. It does not apply to customs and excise duties.

An applicant applying for tax payment support measures is any entrepreneur, natural and legal person, associations without legal personality that perform their economic activity permanently, independently and for the purpose of generating revenue, income, profit, or other economically assessable benefits, that makes it impossible to pay a due tax liability, provided that on the day of filing the claim their tax debt, if any, amounts to less than HRK 200 because that amount corresponds to the minimum cost of an enforcement proceeding. ${ }^{16}$ In the case of a due VAT liability, only an applicant whose tax base is determined based upon the deliveries made can submit a tax deferment application. ${ }^{17}$

According to Mijatović, a taxpayer is considered unable to pay due tax liabilities if they record at least a $20 \%$ reduction in revenue/income in a month preceding the month of application relative to the same month of a previous year, or if the taxpayer expects a revenue/income decline of at least $20 \%$ in the next three months following the month of application relative to the same period of the previous year. ${ }^{18}$

\subsection{Applying for tax relief measures and making decisions thereupon}

A taxpayer who would like to apply for support measures according to the place of residence or place of establishment shall submit a reasoned request in writing to

14 Relief measures to reduce the economic effects of coronavirus II, Liberfin, [https://liberfin.hr/ mjere-za-rasterecenje-gospodarstva-od-posljedica-koronavirusa-ii/?cv=1], Accessed 10 April 2021.

15 Determining the VAT liability pursuant to the new rules, RRIF, [https://www.rrif.hr/Utvrdivanje_obveze_PDV_a_prema_novim_pravilima-1754-vijest/?cv=1], Accessed 10 April 2021.

16 Article 170 of the General Tax Act, Official Gazette Nos. 115/2016, 106/2018, 121/2019, 32/2020, and $42 / 2020$.

17 Tax relief measures in the Republic of Croatia during COVID-19, [https://www.iusinfo.hr/aktualno/u-sredistu/41555], Accessed 10 April 2021.

18 Tax deferral, Deloitte, [https://www2.deloitte.com/hr/hr/pages/about-deloitte/articles/covid-19-odgoda-placanja-poreznih-obveza.html?cv=1], Accessed 10 April 2021. 
the competent tax authority. The tax authority is obliged to decide on the submitted application in a simple and urgent procedure and inform the applicant of its decision appropriately (this can also be done electronically). If the submitted application is assessed by the Tax Administration as justified, deferred payment with no interest will be granted for due tax liabilities. ${ }^{19}$

"Deferred payment is granted for a period of three months, with the deadline commencing on the legally prescribed due date of each individual tax liability. If special circumstances remain in force longer, an additional three-month period may be granted for a deferred tax liability. If an additional period is granted, it is possible to expand the scope of deferred tax liabilities (with no interest included), provided that a new application has been submitted.

In a specific case of a due VAT liability, an applicant whose tax base is determined based upon the deliveries made (VAT deferral does not apply to taxpayers who determine their VAT liability based upon the charges collected) can be granted VAT payment deferral in the amount higher than the amount they would have been liable for if they had calculated VAT pursuant to the tax procedure taking into account charges collected.

Deferral of payment may be granted for the amount of the due tax liability higher than the amount which the taxpayer would have been liable for if they had calculated VAT pursuant to the tax procedure taking into account charges collected. Deferred VAT payments are granted for a three-month period commencing on the due date for the VAT liability payment.

No interest is charged on due tax liabilities for which payment deferral has been granted. The aim of due VAT liability deferral is to oblige the taxpayer, for the duration of special circumstances, to pay VAT on the invoices issued and collected, and the incoming invoices received and paid, while the remainder is treated as a deferred tax liability. If the taxpayer is unable to pay the deferred tax liability at the end of the deferral period, they may request payment in instalments (without any interest included)." 20

Payment of deferred tax liabilities in instalments - for a maximum period of 24 months - may be granted on request to an applicant unable to settle the deferred tax liability after the expiry of the deferral period. In that case, no interest is charged. A written and reasoned request for payment of a deferred tax liability

19 [http://www.tzomedulin.org/g/kutak-za-iznajmljivace/obavijesti-za-iznajmljivace/?cv=1], Accessed 10 April 2021.

20 Instruction on VAT deferral and payment in special circumstances, Tax Administration, Class No. 41019/20-02/129; File No. 513-07-21-01/20-1. 
in instalments may be submitted within five days of the due date of the liability that the applicant is unable to pay. The request for paying deferred tax liabilities in instalments may relate either only to a deferred tax liability due but not paid yet (approval of the application excludes the possibility of applying for payment of deferred tax liabilities in instalments which will become due in the future), or to all deferred tax liabilities (due and outstanding at the time of filing the application), where the deferred tax liabilities that are not yet due become due and their payment in instalments is approved (instead of approving an additional deferral period). If the taxpayer does not comply with the approved deadlines for paying tax liabilities in instalments, the approved instalment agreement will be revoked. ${ }^{21}$

However, if the taxpayer has been granted tax payment deferral and/or instalment payment, the tax authority may subsequently verify the facts on which the previously submitted claims are based and on the basis of which some of the said tax payment support measures have been approved. The tax authority may, as a final measure - if it subsequently determines that the conditions cannot be met - declare the tax payment support measure null and void, i.e. tax liabilities become payable immediately.

In addition, if it is established that during special circumstances the applicant made false statements of material facts by means of which they supported their application and/or acted contrary to tax regulations and/or abused tax payment support measures in order to gain illegal benefits, the tax authority will notify the applicant thereof, and calculate appropriately the relevant tax liability and the applicable default interest rate.

There follows an example of a deferred tax liability taken from the Ministry of Finance: On 2 April 2020, an entrepreneur submitted an application and provided revenue figures for March 2020 relative to March 2019 = a revenue decline of more than $20 \%$ was apparent. The Tax Administration notified the taxpayer as soon as possible that their application was justified. The taxpayer then submitted the JOPPD (i.e. report on income, income tax and surcharge, and contributions for compulsory insurance) payroll form for March due on 5 April 2020 - it was booked on 5 July 2020 while processing the tax liability of the related taxes and contributions. An income tax return for 2019 was filed by the taxpayer on 30 April 2020 - the difference in the form of income tax refund was issued on 31 July 2020. Advance corporate income tax, an advance Tourist Board membership fee, and a Croatian Chamber of Commerce membership fee - due on 30 April 2020

${ }_{21}$ Tax deferral, Deloitte, op. cit., note 18, [https://www2.deloitte.com/hr/hr/pages/about-deloitte/articles/covid-19-odgoda-placanja-poreznih-obveza.html?cv=1], Accessed 10 April 2021. 
- were charged on 31 July 2020. Tax liabilities due in May and June were charged subject to deferral in August and September.

\subsection{Exemption from contribution liabilities for co-financed net salaries}

A taxpayer who gets support from the Croatian Employment Service, which is aimed at co-financing net salaries during the period relating to special circumstances and preserving jobs, is released from the obligation to pay compulsory insurance contributions for the amount of a co-financed net salary. In this case, all contribution liabilities are borne by the state budget.

If circumstances are subsequently determined which did not justify financial support for the net salary paid to the beneficiary, the granted exemption from the contribution liabilities will be declared null and void in the amount of an unjustifiably granted exemption. The application of tax exemption ex officio will be carried out by the Tax Administration (by reducing liabilities on the employer's tax and accounting book of records, on the basis of its own records and data exchanged with the Croatian Employment Service).

The following example shows the employee payroll calculator with financial support provided by the Croatian Employment Service, partial exemption from paying contributions, and deferred payment of the difference in contributions, taxes and surcharges.

APPENDIX 2: Employee payroll calculator - an example

\begin{tabular}{|l|c|l|l|l|}
\hline $\begin{array}{l}\text { Gross salary of HRK } \\
10,000, \text { support of } \\
\text { HRK 4,000 by the } \\
\text { Croatian Employment } \\
\text { Service, and deferred } \\
\text { payment of taxes and } \\
\text { contributions }\end{array}$ & $\begin{array}{l}\text { Salary calcula- } \\
\text { tion (in HRK) }\end{array}$ & $\begin{array}{l}\text { Exemption } \\
\text { from paying } \\
\text { contributions } \\
\text { (proportional } \\
\text { to HRK 4,000 } \\
\text { net) }\end{array}$ & $\begin{array}{l}\text { Deferred pay- } \\
\text { ment of the dif- } \\
\text { ference between } \\
\text { contributions } \\
\text { and taxes }\end{array}$ & $\begin{array}{l}\text { Compulsory } \\
\text { payments to the } \\
\text { employee }\end{array}$ \\
\hline Gross salary & 12,000 & & 1,050 & \\
\hline $\begin{array}{l}\text { Pension insurance - } \\
\text { Pillar 1 15\% }\end{array}$ & 1,800 & -750 & 350 & \\
\hline $\begin{array}{l}\text { Pension insurance - } \\
\text { Pillar 2 } 5 \%\end{array}$ & 600 & -250 & & \\
\hline Total contributions & 2,400 & & & \\
\hline Income & 9,600 & & & \\
\hline Personal allowance & 4,000 & & & \\
\hline Tax base & 5,600 & & & \\
\hline
\end{tabular}




\begin{tabular}{|l|c|c|c|c|}
\hline $\begin{array}{l}\text { Personal income tax } \\
24 \%\end{array}$ & 1,344 & & & \\
\hline $\begin{array}{l}\text { Income tax surcharge } \\
18 \%\end{array}$ & 241.92 & & & \\
\hline Total tax and surcharge & $1,585.52$ & & $1,585.52$ & \\
\hline Net salary & $8,014.08$ & & & $8,014.08$ \\
\hline $\begin{array}{l}\text { Health insurance } \\
16.5 \%\end{array}$ & 1,980 & -825 & 1,155 & \\
\hline Total & 13,980 & $-1,825$ & $4,140.92$ & $8,014.08$ \\
\hline
\end{tabular}

Source: Mazars Extraordinary Tax Newsletter - Supplement, 9 April 2020

\subsection{Tax exemption}

Tax liabilities in this context are taxes, fees, contributions, fines for tax offenses, concession fees and all other imposts that are determined and collected or supervised by the Tax Administration, relative to which the taxpayer has applied for tax relief measures and that are due as of 1 April 2020.

"An applicant is fully exempt from paying taxes if, due to special circumstances, their business activity is prohibited, suspended or significantly hindered by the decisions of the competent authority, and therefore, they record at least a 50\% decline in revenue/income in a three-month period as of 1 April 2020 (a decline in revenue/income is calculated by comparing it with the same period in the previous year).

Provided that in the previous year such taxpayer (applicant) recorded the value of supplies of goods and services of more than HRK 7.5 million (excluding VAT), they will be partially exempt from paying due tax liabilities proportionally to a decrease in revenue/income compared to the same period in the previous year (e.g. if they earned HRK 10 million, they are entitled to a write-off of public imposts amounting to HRK 5.5 million, whereas they can apply for a payment deferral of the remaining HRK 4.5 million). “22

Taxpayers who earn their income by renting flats, rooms and beds to travellers and tourists and organising camps, and pursuant to that basis, pay a lump-sum tax, are entitled to tax exemption in the amount of $1 / 4$ of the annual lump-sum income tax and income tax surcharge. ${ }^{23}$

22 Mijatović, op.cit., note 5.

23 Frequently asked questions related to the package of measures adopted in the spring wave of the epidemic caused by the spread of the COVID-19 virus, Tax Administration, op.cit., note 13, [https://www. porezna-uprava.hr/Stranice/NPP_COVID_mjere.aspx\#covid1?cv=1], Accessed 10 April 2021. 
Taxpayers who registered a drop in revenue/income of at least 30\% in the period from 20 March to 20 June 2020 are entitled to the right to apply for tax exemption. The taxpayer are exempt from paying taxes and other imposts due in the period from 1 April to 20 June 2020. This tax relief measure does not include value added tax, customs duties, excise duties, mandatory pension contributions, taxes and surcharges on final income, imposts on betting, liabilities under previously concluded administrative contracts and liabilities rescheduled from pre-bankruptcy and bankruptcy proceedings. ${ }^{24}$

Taxpayers do not have to apply specifically for this support measure since the Tax Administration will implement this measure ex officio on the basis of the information at its disposal.

\subsection{Corporate tax extension deadline}

A procedural provision is, inter alia, the one on requesting an extension of time to file a corporate income tax return. In special circumstances, the deadline for filing corporate income tax returns was extended to 30 June 2020. Corporate income tax liabilities incurred from such returns were due on 31 July 2020. The above provisions do not apply to taxpayers whose selected tax period does not qualify as a calendar year (e.g. the opening of a bankruptcy procedure, changes in business status, termination of business). ${ }^{25}$

\subsection{VAT exemption}

The next provision is the exemption from VAT on donations. "VAT payers are exempt from paying VAT for goods and services supplied without fees and consideration, and at the same time, necessary to fight the effects of the COVID-19 disease pandemic. VAT exemption in the cases given above applies to supplies made in March 2020 and the first quarter of 2020, due by 30 April 2020, and supplies made by 20 June 2020 .

If VAT exemption is realised in the cases described above, this does not exclude the possibility of deducting tax prepayment for donated goods or services supplied without compensation or consideration that are necessary to combat the effects of

24 Implementation of tax payments and the submission deadlines for financial statements in special circumstances, Deloitte, [https://www2.deloitte.com/hr/hr/pages/about-deloitte/articles/covid-19-mjere-placanje-poreza-predaja-financijskih-izvjesca.html?cv=1], Accessed 10 April 2021.

25 Frequently asked questions related to the package of measures adopted in the spring wave of the epidemic caused by the spread of the COVID-19 virus, Tax Administration, op.cit., note 12, [https://www. porezna-uprava.hr/Stranice/NPP_COVID_mjere.aspx\#covid1?cv=1], Accessed 10 April 2021. 
the COVID-19 pandemic. If goods and services necessary to combat the effects of the COVID-19 pandemic are supplied for a fee or paid for by cash donations, the said VAT exemption shall not apply to such supply. ${ }^{\text {26 }}$

"Exemption from VAT is prescribed on imports of certain goods. On 3 April 2020, the Commission (EU) adopted Decision 2020/491 on relief from import duties and VAT exemption on importation granted for goods needed to combat the effects of the COVID-19 outbreak during 2020. This Decision provides for exemption from value added tax on the final importation of certain goods. Beneficiaries are state organisations (including state bodies, public bodies and other bodies governed by public law), organisations approved by the competent authorities in the Republic of Croatia, or another person importing goods on their behalf. This exemption applies to goods imported until 31 July 2020." 27

\subsection{Administrative contract in special circumstances}

The General Tax Act normally allows the tax authority and the taxpayer to enter into an administrative agreement to settle a tax debt. It can refer to a settlement of a tax debt in full or in part, for a maximum period of 24 months. It is exceptionally allowed to conclude an administrative contract in special circumstances referring to due tax liabilities that are not subject to deferral, i.e. tax liabilities to which no tax exemption applies (provided that they fall due in the three-month period as of 9 April 2020).

Unlike an administrative contract in normal circumstances, an administrative contract in special circumstances includes, inter alia, the following features: statutory default interest reduced by 3 percentage points applies to the repayment period (currently $3.11 \%$ ); the contract can also be concluded without any security for the tax debt; and under certain conditions, it may be concluded even if the taxpayer already has a pre-bankruptcy settlement procedure, a pre-bankruptcy agreement or an administrative contract referring to liabilities due before 9 April 2020. During the administrative contract in special circumstances, the taxpayer may not be granted an administrative contract referring to a tax liability incurred and/or due after the conclusion of the said administrative contract. ${ }^{\text {28 }}$

Instruction on VAT deferral and payment in special circumstances, Tax Administration, op.cit., note 20.

Ibid.

Mijatović, op.cit., note 5. 


\subsection{Advance and annual tax liability payments of personal income tax and corporate income tax under special circumstances}

The Corporate Income Tax Act ${ }^{29}$ stipulates that a taxpayer pays advance tax on the basis of a tax return for the previous tax period. Monthly instalments are paid by the end of the month for the previous month, in the amount obtained when the tax liability for the previous tax period is divided by the number of months of business activity in the same tax period.

"The Decision on measures to limit social gatherings, work in shops, provision of services and the staging of sports and cultural events ${ }^{30}$ came into force on 19 March 2020, which was adopted in order to prevent the coronavirus epidemic and brought a major change in the activities of certain taxpayers. Taking into account the Notification to taxpayers of the reduction of monthly advance personal income and corporate income taxes, ${ }^{31}$ which was published on 26 March 2020 on the Tax Administration website, it can be concluded that the Tax Administration applied the provision of Article 34(2) of the Corporate Income Tax Act in order to reduce advance payment of corporate income and personal income taxes for taxpayers that recorded a decline in business activity by the implementation of given anti-epidemiological measures.

Therefore, pursuant to the aforementioned Notification, and based on the decisions of the competent authorities it is aware of, the Tax Administration reduced advance payment of corporate income and personal income taxes to taxpayers whose business operations were suspended due to special circumstances to HRK 0.00 , starting with tax liability due on 31 March 2020 and advance corporate income and personal income taxes for February 2020.

\subsection{Decision on measures to mitigate the negative consequences on the business of caterers and craftsmen in the City of Zagreb}

The Official Gazette of the City of Zagreb adopted the Decision on measures to mitigate the negative consequences on the business of caterers and craftsmen in the City of Zagreb caused by the epidemic of COVID-19 disease. ${ }^{32}$ Taxpayers are

29 Official Gazette No. 177/2004, 90/2005, 57/2006, 80/2010, 22/2012, 146/2008, 148/2013, $143 / 2014,50 / 2016,115 / 2016,106 / 2018,121 / 2019,32 / 2020$, and 138/2020.

30 Official Gazette No. 32/2020.

31 Notification to taxpayers of the reduction of monthly advance personal income and corporate income taxes, Tax Administration, [https://www.porezna-uprava.hr/Stranice/Vijest.aspx?NewsID=2881\&List=Vijesti], Accessed 10 April 2021.

32 "Službeni glasnik Grada Zagreba“, No. 27 of 30 October 2020, Class No. 021-05/20-01/417, File No. 251-01-03-20-8. 
required to calculate consumption tax at the rate of $2 \%$ and it should be expressed on receipts and on the prescribed PP-MI-PO form that should be submitted by the $20^{\text {th }}$ of current month for the previous month.

The City of Zagreb has transferred the task of determining and collecting consumption tax to the Tax Administration, which will cancel the amounts owed ex officio in accordance with the Decision, thus avoiding additional costs of adjusting to the system that taxpayers could have by implementing the said Decision.

The Tax Administration supervises the legality of general acts issued by representative bodies of cities, and in accordance with its powers, it determines whether the Decision on measures to mitigate the negative consequences on the business of caterers and craftsmen in the City of Zagreb caused by the epidemic of COVID-19 disease was made in accordance with regulations governing the tax procedure.

\section{ENFORCEMENT PROCEEDINGS DURING SPECIAL CIRCUMSTANCES DUE TO AN EPIDEMIC CAUSED BY THE COVID-19 VIRUS}

As of 9 April 2020, the Tax Administration has the right to apply special rules when conducting enforcement proceedings. These rules oblige the Tax Administration not to issue decisions on enforcement on financial assets against all taxpayers during special circumstances, and in the initiated enforcement proceedings against movables from the implementation of the public auction. The Tax Administration will not take enforcement action against real property either.

Special circumstances do not prevent the Tax Administration from issuing warnings to inform the debtor about tax debt, when implementing measures to ensure the collection of tax debt by issuing a decision on enforcing movable assets by seizing; implementing measures to secure the collection of tax debt by placing a lien on the debtor's real estate. "The first amendment to the Act defines special circumstances for the occurrence of which measures were adopted to facilitate the payment of tax liabilities in such a way that tax liabilities can be deferred or settled in instalments with no interest or statute of limitations.

The second amendment enabled the taxpayer entitled to and granted support to preserve jobs, to be exempted from paying public imposts on co-financed net salaries. Also, if due to special circumstances the taxpayer is prohibited from working by the decision of the competent authority, or if their business activities are suspended or significantly hindered, they may be fully or partially exempted from paying taxes and during special circumstances deadlines, VAT on imports and 
donations, the implementation of enforcement measures, interest rates and procedural provisions may be provided for in a different way. " 33

In special circumstances, the taxpayer and the tax authority may enter into an administrative contract for due tax liabilities. An administrative contract in special circumstances is concluded for a debt of more than HRK 200. An administrative contract must contain the following provisions:

- The tax liability stated in the tax and accounting book of records is considered compliant with the tax liability with no certification required.

- Taxpayers express their intention to conclude an administrative contract by submitting a request, and the Tax Administration confirms this by the administrative contract signed by the head of the authority.

- The administrative contract is concluded for 24 months with statutory default interest amounting to $3.11 \%$.

- An administrative contract can be concluded without collateral. ${ }^{34}$

- A taxpayer may enter into an administrative contract even though they have a pre-bankruptcy settlement procedure in force, provided that they have settled all due annuities of the pre-bankruptcy settlement.

A request addressed to the competent Tax Administration office concerning the conclusion of an administrative contract can be submitted via the ePorezna platform, ${ }^{35}$ while taxpayers who are not users of the ePorezna system can send the said request by mail.

The legislator also enacted a measure of relief for natural persons whose portion of income is confiscated for enforcement purposes. In order to make it easier for citizens in these situations to bear the burden of the negative economic consequences of the epidemic, the Act on Enforcement on Financial Assets ${ }^{36}$ was adopted which entered into force on 18 April 2020.

33 Radica, V.; Rudić, D, Ovršni postupak za vrijeme trajanja posebnih okolnosti, Porezni vjesnik, No. 6, June 2020., p. 35-36

34 Frequently asked questions related to the package of measures adopted in the spring wave of the epidemic caused by the spread of the COVID-19 virus, Tax Administration, op.cit., note 12, [https://www. porezna-uprava.hr/Stranice/NPP_COVID_mjere.aspx\#covid1?cv=1], Accessed 10 April 2021.

35 ePorezna is a unique web portal of the Tax Administration and a central place where taxpayers can access the electronic services of the Tax Administration according to the one-stop-shop principle. Services that are available include taxpayer data management, receipt of documents, submission of forms and applications, and many other services. For more details, see: Jerković, E., REDUCING THE TAX COMPLIANCE GAP BY IMPROVING TAX ADMINISTRATION, Josip Juraj Strossmayer University of Osijek, Faculty of Economics in Osijek, Croatia, Hochschule Pforzheim University, Osijek, 2018, pp. 989-990.

36 Official Gazette No. 47/20. 
In these conditions marked by a decline in economic activity, the financial situation of natural persons is significantly more difficult. Consequently, although according to the existing special regulations, debtors are entitled to the right to have part of their income exempt from the enforcement procedure, these amendments enable a temporary suspension of all enforcement procedures on financial assets deposited in the natural person accounts.

\subsection{Enforcement proceedings for the collection of tax debt}

Since during special circumstances the Ordinance on the Implementation of the General Tax $\mathrm{Act}^{37}$ also provides for special provisions relating to enforcement proceedings, the finance minister authorises the head of the tax authority to prescribe the procedure for implementing enforcement measures during special circumstances to be applied for a period of three months following the entry into force of the Act on Amendments to the General Tax Act, i.e. its Article 107(a).

In this regard, the Tax Administration will not initiate enforcement proceedings on the debtor's financial assets to collect its receivables from 20 March 2020 to 20 June 2020, regardless of which debt enforcement proceedings should be initiated and when it is due. During the said period, the Tax Administration will refrain from issuing decisions on enforcement on financial assets, decisions on enforcement on salaries and decisions on enforcement against the debtor's cash receivables to all taxpayers, as well as from conducting the sale of movable property within the framework of initiated enforcement proceedings. Likewise, the Tax Administration will not initiate enforcement proceedings on real estate during special circumstances. It should be emphasised that the Tax Administration will not suspend decisions on enforcement on financial assets received by the Financial Agency before 9 April 2020, except in cases provided for in Article 147 of the General Tax Act. During special circumstances, the Tax Administration will continue to issue warnings to tax debtors for the purpose of notifying them of arrears for which they could possibly use the support measures available under the Ordinance on the Implementation of the General Tax Act. Likewise, the Tax Administration will, regardless of the duration of special circumstances, continue to implement measures to ensure the collection of tax debt by issuing a decision on enforcement of the debtor's movable property and submitting proposals for securing monetary claims by putting a lien on the debtor's real estate. ${ }^{38}$

Official Gazette No. 45/19, 35/20, 43/20 and 50/20.

38 Frequently asked questions related to the package of measures adopted in the spring wave of the epidemic caused by the spread of the COVID-19 virus, Tax Administration, op.cit., note 12, [https://www. porezna-uprava.hr/Stranice/NPP_COVID_mjere.aspx\#covid1?cv=1], Accessed 10 April 2021. 


\subsection{Enforcement on Financial Assets}

The Act on Amendments to the Act on Enforcement on Financial Assets ${ }^{39}$ (hereinafter: the Act on Amendments) entered into force on 18 April 2020. The purpose of the said Act is to adopt relief measures aimed at facilitating the position of natural persons whose portion of income is confiscated for enforcement purposes, all in order to make it easier for them to bear the burden of the negative economic consequences caused by special circumstances.

In addition to citizens, craftsmen and other natural persons engaged in economic activity are also categorised as natural persons whose financial assets related enforcement can be suspended.

The Act on Amendments defines special circumstances as an event or a certain situation that could not be foreseen and could not be affected, and which endangers life and health of citizens, property of greater value, significantly impairs the environment, impairs economic activity or causes significant economic damage. ${ }^{40}$

The Act on Amendments stipulates that during special circumstances the Financial Agency will suspend the implementation of enforcement on financial assets in relation to natural person debtors. Special circumstances last from the date of entry into force of the Act on Amendments until the expiry of a three-month period following its entry into force; however, this period may be extended by a decision rendered by the Government of the Republic of Croatia for an additional three-month period.

There is no statutory default interest during special circumstances. Therefore, the Financial Agency will not charge default interest calculated as set out in the basis of payment for the period of special circumstances. It should be emphasised here that the provision relating to non-existent default interest does not apply only to claims relating to ongoing enforcement proceedings on financial assets, but to all claims in terms of all legal relations with delayed payments. This actually means that during special circumstances in the Republic of Croatia, statutory default interest is not charged at all.

During special circumstances, neither the deadlines stipulated by the Act on Enforcement of Financial Assets ${ }^{41}$ nor those stipulated by a special act related to the duration of an account freeze, i.e. unexecuted payments, are set, except for the

\footnotetext{
39 Official Gazette No. 47/20-

40 Ibid.

41 Official Gazette No. 68/18, 02/20 and 47/20.
} 
deadline for the transfer of seized financial assets that starts when the Financial Agency receives the basis of payment.

Notwithstanding the above, the Financial Agency will not suspend the implementation of enforcement on financial assets in relation to a natural person debtor if enforcement is carried out to settle a claim for legal child maintenance, other claims when enforcement is carried out to settle instalments due in the future, claims on the basis of due but unpaid salaries, salary compensations or severance pay, in the case of security measures in criminal law proceedings and enforcement on a specified purpose account. ${ }^{42}$

If after the suspension of enforcement under the Act on Amendments a natural person debtor has no basis for payment based upon which the Financial Agency continues with the implementation of enforcement, it will send an order to debtor's banks to unblock the bank account within ten working days.

Exceptionally, if during special circumstances a condition arises for the transfer of financial assets seized before the occurrence of special circumstances, the Financial Agency shall issue orders to debtor's banks to transfer seized financial assets to the bailiff.

During special circumstances, the Financial Agency will receive new payment bases issued to natural persons and record them in the Registry, but will not send orders to banks for their execution, i.e. no further action will be taken after their entry in the Registry.

Upon termination of special circumstances, the Financial Agency will continue to carry out enforcement in accordance with the provisions of the Act on Enforcement of Financial Assets, and deadlines suspended by the Amendment Act continue to run.

\subsection{Emergency measures in enforcement and bankruptcy proceedings}

The Act on Emergency Measures in Enforcement and Bankruptcy Proceedings for the Duration of Special Circumstances ${ }^{43}$ (hereinafter: the Emergency Measures Act) entered into force on 1 May 2020, and it defines special emergency measures in enforcement and bankruptcy proceedings during special circumstances caused by the coronavirus pandemic. The purpose of the Emergency Measures Act is to adopt measures to alleviate the position of natural persons whose portion of

\footnotetext{
42 Act on Amendments to the Act on Enforcement of Financial Assets, Official Gazette No. 47/20.

43 Official Gazette No. 53/20.
} 
income is seized due to enforcement on salaries, pensions or other permanent income, economic entities threatened by bankruptcy proceedings, beneficiaries of grants for projects financed from national funds or the European Union budget, and beneficiaries of aid schemes paid due to the occurrence of special circumstances.

The duration of special circumstances provided by the Emergency Measures Act is determined to cover the period starting on the day the Emergency Measures Act entered into force and ending with the expiry of a three-month period following its entry into force, i.e. from 1 May 2020 to 31 July 2020.

The said Act stipulates that during special circumstances all enforcement proceedings are suspended, with the exception of those enforcement proceedings that are carried out to settle claims for legal child maintenance, other claims when enforcement is carried out to settle instalments due in the future, claims on the basis of due but unpaid salaries, salary compensations or severance pay, and in the case of security measures in criminal law proceedings.

In addition to the above exceptions, enforcement will also be carried out in the case when a judge deems it necessary and urgent to carry out the enforcement procedure, taking into account the circumstances of each individual case.

The Emergency Measures Act provides for suspension of all enforcement proceedings during special circumstances; however, enforcement on salaries is especially stressed because in most cases employers do not have necessary knowledge to monitor extensive regulations governing enforcement and in this way, on the one hand, it is easier for employers to monitor regulations, and on the other hand, debtors are guaranteed the proper application of regulations. Pursuant to the provisions of the Emergency Measures Act, enforcement on salaries is carried out such that the employer, i.e. the payer of other permanent remuneration, is obliged to receive new enforcement documents for the purpose of getting the settlement priority, but will not confiscate portion of income for the bailiff.

In relation to bankruptcy proceedings, the Emergency Measures Act stipulates that bankruptcy reasons arising during special circumstances are not a prerequisite for filing bankruptcy proceedings. Exceptionally, the debtor may submit a proposal for opening a bankruptcy proceeding, while the Financial Agency and the bailiff may submit that proposal only for the protection of the interests and security of the Republic of Croatia, nature, the natural environment and human health.

During special circumstances and within the meaning of the Emergency Measures Act, no default interests are due. 


\subsection{Compulsory establishment of a statutory lien}

The Tax Administration may have a lien on movable property and a lien on real estate owned by the debtor.

When it comes to a lien on movable property, a proceeding is initiated by issuing a decision on enforcement through seizure, assessment and sale of property. Since the Act on Emergency Measures in Enforcement and Bankruptcy Proceedings for the Duration of Special Circumstances ${ }^{44}$ stipulates that all enforcement proceedings $s^{45}$ are suspended during special circumstances, it follows that the Tax Administration cannot issue a decision on enforcement during special circumstances, so it cannot seize the debtor's movable property, i.e. get a lien on movable property.

Unlike the aforementioned lien on movable property, a lien on real estate is established such that the Tax Administration submits an application through the State Attorney's Office for compulsory establishment of a lien on the debtor's real estate to the competent court in whose territory real estate is located. Since the Act on Emergency Measures in Enforcement and Bankruptcy Proceedings for the Duration of Special Circumstances does not contain provisions relating to compulsory securing of monetary claims, the decision is left to the judge who will receive a proposal for securing a monetary claim by compulsory establishment of a statutory lien.

\subsection{Support measures to assist debtors whose business activities have been suspended}

Pursuant to the Ordinance on the Implementation of the General Tax Act, ${ }^{46}$ taxpayers or debtors whose business activities have been suspended by the Decision of the Civil Protection Headquarters of the Republic of Croatia and the tax authority may conclude an administrative contract in special circumstances to pay tax debt for tax liabilities due during the said suspension. ${ }^{47}$

The following provisions shall apply to an administrative contract in special circumstances:

44 Official Gazette No. 53/2020 and 83/2020.

45 Nacional, 16 July 2020, [https://www.nacional.hr/za-tri-mjeseca-produzeno-trajanje-posebnih-okolnosti-vezano-za-ovrhe/], Accessed 10 April 2021.

46 Ordinance on the Implementation of the General Tax Act (Official Gazette No. 45/19, 35/20, 43/20, $50 / 20,70 / 20,74 / 20,103 / 20,114 / 20$, and $144 / 20$ ).

47 Notification to taxpayers whose business activities have been suspended by the Decision of the Civil Protection Headquarters of the Republic of Croatia, Tax Administration, 30 December 2020, [https:// www.porezna-uprava.hr/Stranice/Vijest.aspx?List=Vijesti\&NewsID=3075], Accessed 10 April 2021. 
- the tax liability stated on the tax and accounting book of records is considered compliant with the taxpayer, with no certificate of outstanding debt issued by the competent tax authority required,

- taxpayers express their intention to conclude an administrative contract by submitting a request, and the tax authority by signing the administrative contract of the head of the authority or a person authorised by the head of the authority,

- the administrative contract is concluded for a maximum period of 24 months with statutory default interest for the repayment period reduced by 3 percentage points,

- an administrative contract can also be concluded without collateral,

- an administrative contract can also be concluded even if a taxpayer has a pre-bankruptcy settlement procedure, a pre-bankruptcy agreement or an administrative contract in force, provided that they have settled all liabilities due before the entry into force of this article, provided that all due liabilities have been settled by the day of submitting the request for concluding the administrative contract and in accordance with the annuity plan for repayment of the pre-bankruptcy settlement, a pre-bankruptcy agreement or an annuity plan which is an integral part of the previous administrative contract. ${ }^{48}$

A taxpayer whose business activities have been suspended by the Decision of the Civil Protection Headquarters of the Republic of Croatia, and whose liabilities have been rescheduled on the basis of a pre-bankruptcy settlement, a pre-bankruptcy agreement, a bankruptcy plan, an administrative contract or payment in instalments, may submit a request a delay in payment of outstanding rescheduled liabilities from the above procedures that fall due at the time of suspension. $\mathrm{Li}$ abilities for which a grace period has been granted fall due after the last annuity of previously rescheduled liabilities.

No interest is charged on tax liabilities for which a grace period for the payment has been granted. ${ }^{49}$

48 Ordinance on the Implementation of the General Tax Act, op.cit., note 46, see also note 28.

49 Notification to taxpayers whose business activities have suspended by the Decision of the Civil Protection Headquarters of the Republic of Croatia, Tax Administration, 30 December 2020, op.cit., note 47, [https://www.porezna-uprava.hr/Stranice/Vijest.aspx?List=Vijesti\&NewsID=3075], Accessed 10 April 2021. 
The request for the grace period must be submitted no later than 5 days after the annulment of the Decision of the Civil Protection Headquarters of the Republic of Croatia suspending business activities. ${ }^{50}$

\section{CONCLUSION}

The crisis caused by the occurrence of the COVID-19 virus is still ongoing, and according to some scientists, it has not yet reached its peak. Nevertheless, it can be concluded that the Tax Administration is coping well with the new situation.

Given that this situation, i.e. pandemic, as well as other emergencies, is extremely difficult or impossible to predict, the legislator incorporated the measures adopted during the COVID-19 pandemic into laws and bylaws so that they can also be activated quickly and efficiently in the event of a new, unpredictable, and economically dangerous situation.

As already indicated in the introduction, there will always be a certain number of taxpayers who do not settle their tax liabilities, with or without a justified reason. When it comes to justified reasons, this primarily refers to job loss, unpaid salaries or a situation when tax debtors themselves cannot collect their receivables so they cannot settle their own debts either. Unjustified reasons most frequently refer to intentional tax evasion or the disparity of revenue and expenditure in situations where taxpayers spend more than they earn. Regardless of which group they belong to, from the tax aspect, they are all in the same position, i.e. they are in a position to become tax debtors who do not pay their due tax debts on time.

With the advent of this situation and the majority of physical activities switching "online", the electronic tax administration system, i.e. eTax, has largely enabled the normal functioning of the entire system. Usage of such an already existing platform increased, and some of its parts were upgraded and improved in order to facilitate business activity in these conditions and reduce physical presence of customers in the Tax Administration.

The Government has enacted tax measures and amendments to acts and regulations to help the survival of vulnerable sectors of the economy, primarily smalland medium-sized enterprises in those sectors directly affected by the pandemic, such as the hospitality industry or tourism. The most significant measures are,

50 Notification to taxpayers whose business activities have been suspended by the Decision of the Civil Protection Headquarters of the Republic of Croatia, Tax Administration, 30 December 2020, op.cit., note 47, [https://www.porezna-uprava.hr/Stranice/Vijest.aspx?List=Vijesti\&NewsID=3075], Accessed 10 April 2021. 
inter alia, a payment deferral and a reduction of monthly advance payments of personal income tax or corporate income tax, and there was great interest in deferral, i.e. payment of due and deferred tax liabilities in instalments. Many other measures have been introduced to provide assistance, i.e. to protect the survival of legal and natural persons and their material assets due to this pandemic and its consequences.

In order to warn tax debtors of the existence of a due tax debt at the beginning of the tax-debt relationship, the Tax Administration issues a warning to them, which provides the possibility of paying the debt within eight days without initiating enforcement proceedings. In addition, taxpayers have at their disposal the institute of an administrative contract, the conclusion of which, on the one hand, enables the repayment of tax debt in several monthly instalments, and on the other hand, enforcement proceedings cannot be initiated against them as long as the administrative contract remains in force.

Initiation of an enforcement proceeding is an extremely inconvenient procedure for all participants engaged in the procedure and the Tax Administration, i.e. officials working in the Collection and Enforcement Services, pay special attention to choosing the enforcement measure that is both most effective in terms of collecting tax debt and at the same time least painful for the debtor. Consequently, tax debt collection by confiscating financial assets deposited in the bank accounts of debtors is the most common enforcement measure that is resorted to first. The relationship between the amount of debt and the choice of enforcement measure is also taken into account, and by amending the Enforcement Act the legislator tends to protect the most vulnerable groups of tax debtors, i.e. enforcement cannot be initiated on the debtor's property for a debt amounting to less than HRK 40,000. In this way, on the one hand, one wants to prevent a disproportion between the amount of debt and the value of the property that is subject to enforcement, and on the other, the aim is to protect tax debtors who live in the only immovable property they possess.

Legislation is constantly changing, including that concerning enforcement proceedings. The goal of the legislator, and thus the Tax Administration as a national administration authority in charge of tax collection, is not to repress taxpayers with the aim of providing funds for the state budget, but to make the Tax Administration a service to citizens, legal entities and individuals that will help them in their daily business activity.

Despite all the above, the real consequences of this pandemic on the economy of the Republic of Croatia, but also on the world as a whole still cannot be predicted. 
Given that the danger of the virus, but also its consequences on the economy, is still present, it is to be expected that there will most likely be new extensions and amendments to acts and bylaws to make the situation as easy as possible for citizens and reduce the consequences as much as possible.

\section{REFERENCES}

\section{BOOKS AND ARTICLES}

1. Cipek, K.; Hadžić, A., Osvrt na porezne i ekonomske mjere tijekom globalne pandemije bolesti COVID-19, Porezni vjesnik, No. 10, October 2020, p. 27-36

2. Jerković, E., Reducing the tax compliance gap by improving Tax Administration, Josip Juraj Strossmayer University of Osijek, Faculty of Economics in Osijek, Croatia, Hochschule Pforzheim University, Osijek, 2018, pp. 989-990

3. Mijatović, N., Porezne mjere u Republici Hrvatskoj za trajanja COVID(a) -19. (11.05.2020.), IUS-INFO, 2020

4. Radica, V.; Rudić, D., Ovř́ni postupak za vrijeme trajanja posebnih okolnosti, Porezni vjesnik, No. 6, 2020, p. 35-41

\section{LIST OF NATIONAL REGULATIONS, ACTS AND COURT DECISIONS}

1. Act on Amendments to the Act on Enforcement on Financial Assets Official Gazette No. $47 / 20$

2. Act on Amendments to the General Tax Act, Official Gazette No. 42/20

3. Act on Emergency Measures in Enforcement and Bankruptcy Proceedings for the Duration of Special Circumstances Official Gazette No. 53/20

4. Act on Enforcement on Financial Assets Official Gazette No. 68/18, 02/20, 47/20

5. Act on Tourist Board Membership Fees, Official Gazette No. 52/2019

6. Corporate Income Tax Act Official Gazette No. 177/2004, 90/2005, 57/2006, 80/2010, 22/2012, 146/2008, 148/2013, 143/2014, 50/2016, 115/2016, 106/2018, 121/2019, $32 / 2020$, and $138 / 2020$

7. Decision on measures to limit social gatherings, work in shops, provision of services and the staging of sports and cultural events Official Gazette No. 32/2020

8. Instruction on VAT deferral and payment in special circumstances, Tax Administration, Class No. 410-19/20-02/129; File No. 513-07-21-01/20-1.

9. General Tax Act, Official Gazette No. 115/2016, 106/2018, 121/2019, 32/2020, and 42/2020.

10. Ordinance on the Implementation of the General Tax Act Official Gazette No. 45/19, $35 / 20,43 / 20,50 / 20,70 / 20,74 / 20,103 / 20,114 / 20$, and 144/20

11. Ordinance and Amendment to the Ordinance on the Implementation of the General Tax Act, Official Gazette No. 45/19, 35/20, 43/20 and 50/20

12. Ordinance on estimated (lump-sum) taxation of liberal professions (independent personal services) Official Gazette No. 1/20 
13. "Službeni glasnik Grada Zagreba“, No. 27 of 30 October 2020, Class No. 021-05/2001/417, File No. 251-01-03-20-8

\section{WEBSITE REFERENCES}

1. Deloitte, Implementation of tax payments and the submission deadlines for financial statements in special circumstances, [https://www2.deloitte.com/hr/hr/pages/about-deloitte/articles/ covid-19-mjere-placanje-poreza-predaja-financijskih-izvjesca.html?cv=1/], Accessed 2 February 2021

2. Deloitte, Tax deferral, [https://www2.deloitte.com/hr/hr/pages/about-deloitte/articles/covid-19-odgoda-placanja-poreznih-obveza.html?cv=1/], Accessed 2 February 2021

3. IUS INFO, Tax relief measures in the Republic of Croatia during COVID-19, [https://www. iusinfo.hr/aktualno/u-sredistu/41555/], Accessed 15 March 2021

4. Liberfin, Relief measures to reduce the economic effects of coronavirus II, [https://liberfin.hr/ mjere-za-rasterecenje-gospodarstva-od-posljedica-koronavirusa-ii/?cv=1/], Accessed 30 March 2021

5. Nacional, 16 July 2020, [ https://www.nacional.hr/za-tri-mjeseca-produzeno-trajanjeposebnih-okolnosti-vezano-za-ovrhe//], Accessed 30 March 2021

6. RRIF, Determining the VAT liability pursuant to the new rules, [https://www.rrif.hr/Utvrdivanje_obveze_PDV_a_prema_novim_pravilima-1754-vijest/?cv=1/], Accessed 15 March 2021

7. Tax Administration, Decision of the Civil Protection Headquarters of the Republic of Croatia, 30 December 2020, [https://www.porezna-uprava.hr/Stranice/Vijest.aspx?List=Vijesti\&Ne wsID=3075/], Accessed 15 March 2021

8. Tax Administration, Frequently asked questions related to the package of measures adopted in the spring wave of the epidemic caused by the spread of the COVID-19 virus, [https://www.porezna-uprava.hr/Stranice/NPP_COVID_mjere.aspx\#covid1?cv=1/], Accessed 15 March 2021

9. Tax Administration, Notification to taxpayers of the reduction of monthly advance personal income and corporate income taxes, [https://www.porezna-uprava.hr/Stranice/Vijest.aspx? Ne wsID=2881\&List=Vijesti/], Accessed 11 March 2021

10. [http://www.tzomedulin.org/g/kutak-za-iznajmljivace/obavijesti-za-iznajmljivace/?cv=1], Accessed 30 March 2021

11. [https://read.oecd-ilibrary.org/view/?ref=128_128575-o6raktc0aa\&title=Tax-and-FiscalPolicy-in-Response-to-the-Coronavirus-Crisis], Accessed 15 March 2021

12. [https://esavjetovanja.gov.hr/ECon/MainScreen?cv=1\&entityId=9961], Accessed 15 March 2021 